\title{
DO DESTERRO AOS PORÕES DA DITADURA: A MEMÓRIA E AS SUBJETIVIDADES DE UMA MILITANTE NA RESISTÊNCIA POLÍTICA
}

\author{
Ary Albuquerque Cavalcanti Júnior ${ }^{1}$
}

\section{Introdução}

Existe um grande consenso na historiografia quanto à importância do ano de 1968 não apenas no âmbito cultural, mas, também como marco do endurecimento da repressão em seus variados campos, algo potencializado com a assinatura do Ato Institucional Número $5 .^{2}$ Nesse cenário, a participação de estudantes secundaristas e universitários se fez de grande importância. Influenciados, principalmente, por ideologias marxistas-leninistas, parte da juventude passou a questionar o mundo e suas bases autoritárias na tentativa de romper com padrões até então estabelecidos. ${ }^{3}$ Contudo, é importante rechaçar que existe uma mítica sobre o ano de 1968 como um período de maciça militância, quando na realidade também houve muitos jovens que optaram por ser indiferentes à política, perfazendo uma reflexão do ponto de vista do quão heterogêneo foi a participação da juventude e seus caminhos políticos. ${ }^{4}$ Pois, se para alguns, questionar, e se posicionar a partir de teorias ditas de esquerda foi um divisor de águas em suas vidas, para muitos, foi um caminho de grande experimentação. ${ }^{5}$

Assim, o movimento estudantil brasileiro em seus mais variados campos de atuação, teve uma grande repercussão de luta e resistência contra a ditadura militar instaurada em 1964, ganhando o devido destaque, principalmente, após a abertura política, quando muitos trabalhos de memórias passaram a relembrar os fatos que marcaram suas vidas.

Outro aspecto importante é a visão que perdurou durante muitos anos, o qual estados da região Nordeste do Brasil funcionaram apenas como locais de recuo/fuga de muitos militantes em via das perseguições e prisões realizadas em lugares como o Rio de Janeiro e São Paulo. Contudo, não apenas rechaçamos essa visão como destacamos que na Paraíba, Bahia, Pernambuco, Sergipe etc., a ditadura foi tão repressora como em qualquer lugar do Estado Brasileiro, bem como se viu o surgimento de inúmeros focos de resistência e de militantes engajados. ${ }^{6}$

Nessa conjuntura, o presente artigo tratará das memórias e dos momentos que marcaram a vida politica de Maria Liége, estudante e militante politica da época, observando a participação intrínseca da subjetividade em sua rememoração. Bem como, propor, a partir da região nordeste refletir sobre uma atuação de grande importância desse espaço regional no âmbito da luta política contra ditatorial brasileira.

\footnotetext{
${ }^{1}$ Doutorando pelo Programa de Pós-Graduação em História da Universidade Federal da Grande Dourados (UFGD). Membro do Laboratório de Estudos de Gênero, História e Interculturalidade (LEGHI/ UNESCO). Bolsista CAPES. E-mail: academicoary@gmail.com.

${ }^{2}$ O Ato Institucional No 5 foi assinado em 13 de dezembro de 1968 e teve como uma de suas principais medidas o fim dos direitos constitucionais e o controle total do Estado. Assim, o fechamento do Congresso Nacional, direito de cassar mandatos, suspensão de direitos políticos, demitir, aposentar etc funcionários públicos e também juízes retirando-o garantias judiciais, confisco de bens, julgamento de crimes políticos pelo Tribunal Militar, alterar leis sem prévio anuncio entre outras medidas arbitrárias. MOREIRA ALVES, Maria Helena. Estado e oposição no Brasil (1964-1984). São Paulo: Edusc, 2005.

${ }^{3}$ HAGEMEYER, Rafael Rosa. Movimento estudantil 68: imagens da paixão. Dissertação. Programa de Pós-Graduação de História da Universidade Federal do Paraná. Curitiba, 1997.

${ }^{4}$ BRITO, Antônio Mauricio F. O golpe de 1964, o movimento estudantil na UFBA e a resistência à ditadura militar (19641968). Tese (doutorado) - Universidade Federal da Bahia, Faculdade de Filosofia e Ciências Humanas. Salvador, 2008.

${ }^{5}$ RAGO, Margareth. A aventura de contar-se: feminismos, escrita de si e invenções da subjetividade. Campinas, SP: Editora da Unicamp, 2013.

${ }^{6}$ SOUZA, Sandra Regina Barbosa da Silva. "Ousar lutar, ousar vencer”: histórias da luta armada em Salvador (1969-1971). Salvador: EDUFBA, 2013.
} 


\section{A experiência no desterro e as influências na luta contra a ditadura}

Maria Liége é uma mulher atuante no cenário nacional, tendo uma militância ativa no Partido Comunista do Brasil ( $\mathrm{PC}$ do $\mathrm{B}$ ), onde desenvolve atividades em prol igualdade de gênero e da democracia. Nascida em Teresina no Piauí, em 1944, perdeu sua mãe ainda muito jovem, tendo o pai assumido função de criá-la juntamente com seus oito irmãos. Por volta dos 10 anos de idade mudouse para a Salvador, Bahia, após rápida passagem pelo Rio de Janeiro, local onde iniciou as bases sociais e politicas de sua vida.

Nos primeiros anos em Salvador, Maria Liége, menciona ter percebido os problemas sociais $e$ politicas que estavam ocorrendo no país. A partir dessa constatação e de sua maturidade, por volta de seus vinte anos, funda juntamente com outros jovens do bairro Desterro, grupo Berimbau, onde passam a realizar atividades de cunho social, além de promover discussões da realidade brasileira.

Nós tínhamos um grupo de jovens ali no Desterro que num primeiro momento a gente frequentava a igreja de Santana e organizávamos a missa da juventude, depois criamos um grupo de jovens que se chamava Berimbau. (...) Então nós fazíamos atividades esportivas, nós fazíamos festinhas cada mês na casa de um e tínhamos atividades de debate. ${ }^{7}$

Ainda segundo Maria Liége esse foi o primeiro passo para seu engajamento político, algo que foi potencializado a partir da inserção de jovens universitários convidados para acrescentarem os debates.

Convidávamos pessoas progressistas da universidade. Da escola de Serviço Social que faziam palestras para gente. A partir daí nós tomamos contato com a $\mathrm{AP}^{8}$ na época. Então nós começamos a ter militância nessa questão de jovens, organizando jovens, debatendo. ${ }^{9}$

A participação de grupos de esquerda em movimentos sociais, representações de bairro etc, era algo que ocorria de forma maciça, não apenas para arregimentar potenciais militantes, mas, também no processo de conscientização politica. No tocante ao grupo Berimbau, a presença de algumas pessoas ligadas a Ação Popular (AP) deu maior consistência politica e apoio, algo que fora realizado em muitos outros pelo Brasil.

Na Bahia, durante a década de 60, a Ação Popular (AP) teve uma participação social e política importante. Ações como o Movimento de Educação Popular ${ }^{10}$ na periferia de Salvador, além de atividades conjuntas com o Movimento de Educação de Base, promovendo educação e politização, passaram a aproximar a AP não apenas de parte da população, mas, também de sindicatos, e outros grupos conhecidos como minoritários.

Em 1967, Maria Liége ingressou no curso de Biblioteconomia da Universidade da Bahia (UBA), futura Universidade Federal da Bahia, e já com a experiência das discussões realizadas no grupo

\footnotetext{
${ }^{7}$ Entrevista de Maria Liége fornecida a Ary Albuquerque Cavalcanti Júnior em 09/09/2015.

${ }^{8}$ A Ação Popular foi instituída em 1962, na cidade de Belo Horizonte, Minas Gerais, formada por integrantes da Juventude Universitária Católica (JUC). Sendo uma das correntes que criticaram as etapas e concepções da revolução socialista galgadas pelo Partido Comunista Brasileiro (PCB) e pelo Partido Comunista do Brasil (PC do B). Ainda que de base socialista, este era marcado pela influencia de pensadores católicos, inspirando um "socialismo humanista". "Dessa forma, a AP se alinhava às organizações que preconizavam uma revolução socialista para o Brasil. Ressalvando não se tratar da "possibilidade de uma revolução imediata" mas de "ordenar o trabalho e as conquistas atuais a uma preparação ativa desse processo". ARAÚJO, Maria Paula Nascimento. A utopia fragmentada: as novas esquerdas no Brasil e no mundo na década de 1970. Rio de Janeiro: FGV, 2001, p. 81.

${ }^{9}$ Entrevista de Maria Liége...

${ }^{10}$ No início da década de 60 muitos grupos já se organizavam no intuito de promover a Educação Popular, algo motivado pela falta de coordenação nacional no âmbito da educação e as falhas de algumas campanhas de governo como a de Educação de Adolescentes e Adultos do Departamento Nacional de Educação (DNE). Como principais participantes tiveram destaque, liberais, as esquerdas marxistas e os católicos influenciados por uma nova filosofia transformadora. Dentre os principais movimentos surgidos no período tem-se os Centros Populares de Cultura (CPC) vinculado a União Nacional dos Estudantes (UNE), Movimentos de Cultura Popular (MCP) e o Movimento de educação de Base (MEB). KREUTZ, Locio. Os movimentos de educação popular no Brasil, de 1961-64. Dissertação (mestrado). Programa de Pós Graduação em educação, UFRJ, Rio de Janeiro, 1979.
} 
Berimbau e o contato com a AP, se aproxima ainda mais da organização de esquerda, a qual passou a fazer parte. Ainda em 1967, é eleita presidenta do Diretório Acadêmico (D.A) de seu curso, algo que potencializará ainda mais sua militância, pois ingressa no movimento estudantil.

Nós tínhamos também um grupo de estudo para conhecer essa realidade. Estudávamos Caio Prado, Werneck Sodré e logo depois que eu entrei na escola de biblioteconomia, que na época era biblioteconomia e documentação e depois virou biblioteconomia e comunicação, eu logo depois fui eleita presidente do diretório acadêmico da escola. E participava de todas as atividades do movimento estudantil aqui na Bahia. ${ }^{11}$

Assim, como no caso de muitos militantes, é possível perceber o quanto a experiência estudantil teve grande importância na vida de muitos jovens. Pois, foi nesta fase que Liége passou da experiência com seu grupo local e adentrou a Universidade. Com tais experimentações, foi se dando a formação política-ideológica, e a delinear as bases de seu engajamento politico, algo que até os dias de hoje apresentam significância em suas reminiscências.

Destacamos que entre o período de 1964 e 1968, o qual Maria Liége perpassa as experiências do grupo Berimbau, entra na universidade, se junta a AP e torna-se presidenta do D.A, o governo militar já havia assinado uma série de medidas repressivas e perseguições já eram realizadas. No limiar estudantil, já haviam sido colocadas em funcionamento a Lei Suplicy $(1964)^{12}$ e o Decreto Aragão (1967). ${ }^{13}$ Assim a vida acadêmica em 1967 já se encontrava bastante turbulenta e com o cerceamento de muitas atividades estudantis.

\section{Militância e clandestinidade}

Em um período onde as bases do Estado se encontravam institucionalizadas e a repressão já não era mais novidades, em 1968, Liége fará não apenas parte da direção do Diretório Acadêmico de Biblioteconomia, como também da delegação baiana presente no XXX Congresso da União Nacional dos Estudantes $(\mathrm{UNE})^{14}$ que seria realizado em Ibiúna ${ }^{15}$ no estado de São Paulo. Ainda que para muitos militantes e líderes a ida ao congresso ser uma ação arriscada, devido a todo aparato repressivo já em funcionamento, muitas delegações chegaram ao interior.

No âmbito dos ideários e paixões que motivavam aquela ala da juventude, enquanto para alguns a ideia de uma revolução, ainda que não muitos fizessem ideia inicial, faziam seus corações palpitarem, para alguns foi uma forma de libertação de amarras culturais a exemplo da presença da mulher na militância ${ }^{16}$. Além disso, muitos jovens passaram a caminhar numa contracultura do que se dizia "correta", passando a usar roupas coloridas, e realizavam ações contra o conservadorismo moral da época.

\footnotetext{
${ }^{11}$ Entrevista transcrita a partir do relato concedido na Comissão da Verdade Milton Santos da Universidade Federal da Bahia em 2013. Disponível em: http://www.comissaoverdade.ufba.br/node/10 Acessado em 10/07/2015

${ }^{12}$ Tentativa do governo de controlar as representações estudantis, subordinando os órgãos estudantis ao Estado. Ver: CRUZ, José Vieira da. A reação estudantil à Lei Suplicy no Nordeste do Brasil: um estudo comparativo entre os estados da Bahia, de Sergipe, Pernambuco e do Rio Grande do Norte, 1964-1967. Anais do Seminário Internacional História do tempo presente, Florianópolis: UDESC; ANPUH-SC; PPGH, 2011.

${ }^{13}$ Medida ainda mais repressiva pelo Estado, extinguindo o Diretório Central dos Estudantes e criando a Conferência Nacional do Estudante Universitário, convocada pelo ministro da Educação. Além de proibir qualquer menção politicaideológico, religioso e racial. ver: CPDOC (2018). Disponível em: http://www.fgv.br/cpdoc/acervo/dicionarios/verbetetematico/decreto-aragao-educacao Acessado em 21/07/2018 s 13h39.

${ }^{14}$ A União Nacional dos Estudantes foi fundada ainda no período do governo Vargas, em 1935 com o intuito de representar os estudantes brasileiros nos mais variados campos de atuação social. Participantes ativos em momentos como a campanha "O petróleo é nosso", o apoio ao envio de tropas brasileiras para combater na segunda grande guerra e as campanhas alinhadas ao governo Joao Goulart. Contudo, com o golpe civil-militar em 1964, nas primeiras horas tem sua sede incendiada, sendo posta em 1967 na ilegalidade, sendo substituída pelo Diretório Nacional dos Estudantes sob os olhares e cuidados militares. Ver: HEGEMEYER, Movimento estudantil 68...; BRITO, O golpe de 1964...

${ }^{15} \mathrm{O}$ nome de Maria Liége esta presente na lista realizada pelo DEOPS/ SP na pasta intitulada Operação Ibiúna - XXX Congresso da extinta UNE, quanto às pessoas que estavam presentes no sítio em Ibiúna.

${ }^{16}$ BORDIN, Laura Beal; LORIANNY, Suelen. Sem liberdade, eu não vivo - Mulheres que não se calaram na ditadura. Curitiba: Compactos, 2013.
} 
Outro ente importante para muitos militantes foi a presença da família, não apenas na resistência politica, mas principalmente no campo emocional. ${ }^{17}$ Nessa perspectiva, Liége retrata a figura do pai como ente importante e com um sentimento de grande admiração.

Um cara que eu admiro muito, porque ele respeitou. Ele era bancário, tinha posições progressistas, era autodidata. Aprendi com ele o gosto pela leitura, porque ele era um cara que lia muito e sempre respeitou a decisão de participação. Porque um pai naquela época, pai de nove filhos, onde desses nove, sete eram mulheres. E tínhamos na época duas atuantes que iam para a manifestação. Às vezes ele ia assistir e dizia: Como vocês ficam numa atividade daquela? Correndo não sei o que, perigo. Ele nunca cerceou nossa atividade. Sempre respeitou e, por exemplo, quando fui para a clandestinidade ele também chegou a me visitar na clandestinidade. Então ele era um progressista democrata, que sempre respeitou a atuação de suas filhas. Então eu tenho uma grande admiração por ele. Não só por isso, mas, também por isso. ${ }^{18}$

A partir do trecho destacado, observamos que em sua memória de militante, Maria Liége destaca o pai como um símbolo de sua identidade militante, principalmente por entender suas decisões. Importante destacar que muitas famílias não seguiram a mesma ideia apresentada neste caso, rompendo relações com filhos e familiares por conta de suas escolhas políticas. Da mesma forma, entendemos que muitas dessas ações foram motivadas por medo, porém, muitas famílias também apoiaram, ainda que de forma indireta seus entes queridos como o caso de Maria Liége. Assim, se torna imprescindível observar a memória não apenas alicerçada no eu memorialista, mas nas suas múltiplas raízes formativas. A família, por exemplo, traz uma enorme significância para a identidade e a construção de uma memória coletiva, algo observado na formação fraternal de Liége e sua relação com seu pai em seu processo formativo. ${ }^{19}$

Em 1969, com o AI-5 em pleno funcionamento, Maria Liége é impedida de se matricular na universidade devido a sua participação no Congresso de Ibiúna. Segundo ela, tal fato antecedeu o que posteriormente ficou conhecido como Decreto 477, o qual proibia qualquer tipo de manifestação politica, como greves, passeatas entre outras ações no interior de escolas e universidades, onde os envolvidos perderiam o direito de se matricular durantes três anos.

Outro aspecto importante nas reminiscências de Maria Liége é a fraternidade e o senso de coletividade entre ela e seus "companheiros e companheiras". Isso é possível observar não apenas em sua memória, mas em tantos trabalhos e obras memorialísticas sobre o período, onde a fraternidade $e$ a partilha de ideais $e$ sonhos traziam ainda mais força $e$ apoio na militância que estavam inseridos. ${ }^{20}$

Ainda em 1969, alguns estudantes tentaram realizar algumas ações isoladas, como na visita do empresário norte americano Nelson Rockfeller ao Brasil. ${ }^{21}$ Sabendo do cenário, foi disposto um grande efetivo de militares no intuito de evitar possíveis atos de oposição, prendendo preventivamente mais de 6.000 pessoas $^{22}$. Segundo Liége houve um ato no Estado da Bahia.

Em 69 nós fizemos uma grande movimentação aqui na Bahia, que este fato para mim

\footnotetext{
${ }^{17}$ COLLING, Ana Maria. A resistência da mulher à ditadura militar no Brasil. Rio de Janeiro: Rosa dos Tempos, 1997.

${ }^{18}$ Entrevista de Maria Liége...

${ }^{19}$ DELGADO, Lucíola de A. Neves. Historia oral: memória, tempo, identidades. $2^{\text {a }}$ Ed. Belo Horizonte: Autêntica, 2010.

${ }^{20}$ Sobre solidariedade ver: JOFFILY, Olivia Rangel. Esperança equilibrista: Resistência feminina á ditadura militar no Brasil (1964-1985). Tese de doutorado, São Paulo: PUC-SP, 2005.

${ }^{21}$ Empresário de grande prestígio nos Estados Unidos que juntamente à AIA (American International Association for Economic and Social Development) teve grande influência no cenário econômico externo de alguns países da América Latina a partir de missões atribuídas pelo seu país. No Brasil, em 1969 realiza uma visita, algo que para muitos movimentos sociais, culturais e figuras como Tom Zé representava a lógica do imperialismo Norte Americano predominando no Brasil. "Nessa perspectiva, Nelson Rockefeller era visto como um dos principais representantes da dominação econômica, política e cultural dos EUA sobre o Brasil, fato que teria gerado resistências por parte de diversos setores". SILVA, Claiton Marcio da. Nelson Rockefeller e a atuação da American International Association for Economic and Social Development: debates sobre missão e imperialismo no Brasil, 1946-1961. História, Ciências, Saúde - Manguinhos, Rio de Janeiro, v.20, n.4, out.- dez. 2013, p. 1699.

${ }^{22}$ SANTANA, Ediane Lopes de. Em nome da Família, da moral e da propriedade: Amém! - As mulheres baianas na organização da Marcha da Família em Salvador 1962-1964. (Dissertação). Programa de Pós-graduação em História Social. Universidade Federal da Bahia, Salvador. 2009 
é um fato inédito e histórico e maravilhoso, porque várias correntes do movimento estudantil na Bahia se uniram para fazer uma manifestação contra o imperialismo Norte Americano e o fora Rockfeller. E não só fizemos uma pichação nessa cidade como nunca foi visto. Eu e minha equipe de pichação fomos encarregados de pichar a Escola de Medicina da Bahia ali no Terreiro dentro do pátio. Tivemos que ir pelo Pelourinho pular o muro da escola e pichar a escola, pular de volta e no dia seguinte estava maravilhosamente pichado todos os lugares (...) Era a Joana Angélica, era a arcada da Cidade Baixa, em todos os lugares tinha "Fora Rockfeller" e "Abaixo Imperialismo Americano". Eu acho que foi uma das ações unitárias de todas as correntes do movimento estudantil aqui na Bahia. ${ }^{23}$

Contudo, com a cassação imposta aos estudantes houve a desestruturação do Movimento Estudantil "ao dilacerar suas lideranças e afastá-las legalmente do convívio universitário" ${ }^{24}$ Assim, segundo constatam algumas bibliografias não houve qualquer tipo de ato maior no estado da Bahia. Logo, Liége menciona um episódio diferente daqueles até então pesquisados pela historiografia baiana sobre o período, haja vista que não foram encontrados indícios de tal ocorrência. Neste ponto, entre um estudo historiográfico e a memória, está um dos grandes desafios da história oral, sua relação com inúmeras temporalidades, onde o jovem do passado fala pelo adulto do presente. Dessa forma, não é tarefa do pesquisador fazer qualquer espécie de julgamento memorialístico, mas ter consciência dos métodos históricos e dos inúmeros fatos não documentados que só possuem registros através da oralidade. Ainda em continuidade ao ato e a prisão, conta Maria Liége:

(...) caminhando para a Escola de Engenharia da Federação, eu e duas colegas de biblioteconomia, indo para a um ato especialmente contra o imperialismo e "fora Rockfeller". Aí quando chegamos na Escola de Engenharia disseram que a Polícia Federal tinha cercado o local e tinha sido resolvido que a manifestação seria na Escola de Arquitetura e nós três fomos caminhando para a Escola de Arquitetura. Nessa ocasião, veio um carro com Luís Arthur ${ }^{25}$ e me reconheceu, porque recentemente eu tinha estado com ele e meu pai. Ele mandou parar o carro e disse: - Pega, segura que é ela. E aí nós tentamos descer aquelas ribanceiras da Federação, mas eles nos prenderam e nos levaram ali para a polícia feminina ali na Piedade [Liége fica presa durante oito dias - grifo nosso]. E as duas, e eu tive que ouvir dele, porque os pais das outras duas foram chamados e ele disse: não deixa ela andar com esse mal elemento, porque essa dai é má influência para as suas filhas. ${ }^{26}$

Com uma riqueza de detalhes, percebemos em sua narrativa, os ideários de uma juventude e o fôlego característico das muitas histórias de ações realizadas, algo marcado pelas lentes do presente e pela subjetividade da autoafirmação de quem rememora. Além disso, seu relato nos possibilita problematizar algumas visões acerca das pessoas que militavam politicamente, ainda mais sendo mulheres, externando a clara distinção de gênero e a cultura machista vigente. A partir das relações de poder $^{27}$ que se faziam presentes, não apenas no âmbito político, mas na construção de gênero, a qual colocava as mulheres em lugares "privados", percebe-se que a possível fala do policial se remete a propor que por suas ações Maria Liége não era uma boa influência para as filhas dos pais que foram busca-las. Tendo por base o padrão de mulher estabelecido naquela sociedade, a qual não se envolve com politica, a fala vai mais além o que uma construção geral de ser um mal elemento, mas sim, parte de uma compreensão do policial do que as outras meninas se tornariam se permanecessem no convívio com Liége. Sobre a o sujeito feminino e a política:

\footnotetext{
${ }^{23}$ Entrevista transcrita a partir do relato concedido à Comissão da verdade Milton Santos da Universidade Federal da Bahia em 2013. Disponível em: http://www.comissaoverdade.ufba.br/node/10.

${ }^{24}$ BRITO, O golpe de $1964 \ldots$, p. 185

${ }^{25} \mathrm{O}$ coronel Luiz Artur, foi Secretário de Segurança Pública da Bahia e participou ativamente da repressão que assolou o Brasil, tendo destaque no estado da Bahia, a partir de seu envolvimento em inúmeras prisões, cercos e torturas, como a do ex-deputado Emiliano José. Disponível em: http://novo.fpabramo.org.br/sites/default/files/4.perseuespecial.jose.pdf. Acesso em 28/09/2018.

${ }^{26}$ Entrevista transcrita a partir do relato concedido à Comissão da verdade Milton Santos da Universidade Federal da Bahia em 2013. Disponível em: http://www.comissaoverdade.ufba.br/node/10

${ }^{27}$ FOUCAULT, Michel. A ordem do discurso. São Paulo, Loyola, 1996.
} 
A trajetória da construção do sujeito político feminino é marcada por práticas sociais e projetos específicos da sociedade. O reconhecimento das mulheres como sujeitos políticos encontra barreiras na tentativa de desconstrução porque rompe com os padrões estabelecidos pela família e pela sociedade, que determinou códigos masculinos de participação pública e política. ${ }^{28}$

Após sua saída da prisão, ainda em 1969, algo sem grandes dificuldades, segundo Liége, conheceu sua terceira prisão, ocorrida em ação conjunta com outros estudantes, quando vão assistir a uma peça teatral encenada no Teatro Castro Alves (TCA), sendo na época considerada subversiva.

Por conseguinte, após sua terceira prisão, em contato com membros da AP, Liége é recomendada a sair de Salvador, devido às perseguições que vinha sofrendo. Dessa forma, inicia sua vida na clandestinidade no estado de Fortaleza em 1970 onde passou dois anos, até se mudar para o Recife em 1972.

No tocante à clandestinidade, para muitas militantes essa foi uma das principais alternativas, principalmente após o $\mathrm{AI}-5$, em meio às perseguições que passaram a se intensificar. Logo, "(...) a morte, a prisão, a clandestinidade e/ou o exílio tornaram-se os destinos quase certos dos militantes políticos envolvidos em movimentos de resistência à ditadura" ${ }^{29}$ Dessa forma, como Maria Liége relata "algumas pessoas foram obrigadas a sair do país, foram viver no exílio. O meu exílio foi no próprio Brasil". 30

Durante o período que viveu em Fortaleza, aproximadamente dois anos, Maria Liége passou a dividir uma casa com outros companheiros da AP, onde trabalhava em uma loja de departamentos e militava. Será vivendo no estado que reencontrará Arthur de Paula ${ }^{31}$, também militante das AP, com quem se casou e mudou-se para a cidade de Recife, Pernambuco.

No Ceará trabalhei em uma loja de departamento depois eu trabalhei numa indústria que tinha sido (...). Era uma equipe daqui de São Paulo que foi para lá. Era uma indústria de confecções. Era Vezil Industrial de Roupas. Companhia Vezil Industrial de Roupas. E aí eu trabalhei nessa loja de departamento depois eu fui trabalhar nessa fábrica. Aí eu trabalhei dois anos. ${ }^{32}$

Com o exposto acima, é possível tecer algumas reflexões quanto à militância $e$ a vida social dos militantes. Muitas mulheres e homens tiveram que trabalhar para conseguir seu sustento enquanto realizavam atividades partidárias e de oposição. Além disso, na luta política muitos abandonaram a universidade e ciclos sociais, deixando seus projetos individuais em nome de um projeto político coletivo, de um ideal, principalmente ao adentrar na clandestinidade como no caso de Liége. Logo, a relação entre trabalho e militância não era algo destoante da vida de muitas militantes politicas, ao passo que continuavam a participar de suas atividades partidárias enquanto trabalhavam.

Apesar de toda limitação de uma vida na clandestinidade, marcada por uma série de cuidados cotidianos, segundo Maria Liége, isso não impedia uma vida normal dentro do possível.

Nós éramos pessoas normais. Vivíamos como pessoas normais. As pessoas namoravam, casavam. Eu conhecia ele desde Salvador, mas só fomos casar em Recife [...] Foi quando a gente se reencontrou. Então as pessoas, por exemplo, [...] Um casal que eu morei com eles eram casados na clandestinidade [...] As pessoas casavam, viviam e tinham filhos. Então eu conheci outras pessoas como Marta Machado, morei com ela, era casada e tinha filhos. As pessoas viviam dentro do possível na normalidade como qualquer outra pessoa. Só não podia dizer quem eles eram. E não podiam militar da forma que queriam e nem se manifestar da forma que

\footnotetext{
${ }^{28}$ COLLING, A resistência..., p. 95.

${ }^{29}$ ARAUJO, Maria Paula; SILVA, Izabel Pimentel da; SANTOS, Desirree dos Reis. Ditadura militar e democracia no Brasil: história, imagem e testemunho. 1 ed. Rio de Janeiro: Ponteio, 2013, p. 23.

${ }^{30}$ Entrevista de Maria Liége...

${ }^{31}$ Assim como Maria Liége, Arthur Geraldo Bonfim Paula militou na AP, tendo atividades políticas em estados como São Paulo, Minas Gerais, Bahia, Ceará e Pernambuco.

${ }^{32}$ Entrevista de Maria Liége... 
queriam. Mas as pessoas viviam, amavam, casavam tinham filhos, namoravam [...]. ${ }^{33}$

Em vida clandestina, Liége afirma que optou por não trocar de nome ou identidade, "Eu usava meu nome. O pessoal me chamava de Lia ou de Maria. Então eu vivi com minha identidade mesmo. Eu trabalhei e tinha uma vida normal" ${ }^{34}$ Diferente de muitas memórias do período nas quais a vida na clandestinidade significava não apenas o rompimento com os laços afetivos anteriormente construídos, mas a própria identidade, onde Maria Liége não se enquadra neste perfil ${ }^{35}$, no tocante a seu nome. Contudo, levamos em consideração o amplo aparato de cerceamento de ações e liberdades que a clandestinidade infligia, sendo o nome, nesse caso, apenas um detalhe.

Vendo-se as duras condições que a vida na clandestinidade impunha, entende-se por que o recurso a esse tipo de sobrevivência era protelado ao máximo - sobretudo o da clandestinidade completa, que geralmente ocorria quando outros membros da organização eram presos, o que colocava a vida dos outros companheiros em sério risco. Assim, muitas das atividades "subversivas" foram praticadas por indivíduos que ainda mantinham uma vida legal, com endereço certo, emprego ou local de estudos conhecidos $[\ldots]^{36}$

Contudo, também observamos a clandestinidade não seguindo modelos pré-existentes a partir de memorias, mas composta de heterogenias, que variavam em grau de cargos e militância dos envolvidos. O ato de ser chamada de Lia ou Maria, apesar de não ser algo tão diferente de seu nome, representam apelidos que não apresentam tanta precisão em uma possível apreensão, haja vista que existiam muitos codinomes "Maria", um nome bem recorrente no país.

Ainda no tocante á vida clandestina, além dos cuidados diários relacionados à realização de reuniões e em atos de militância, a comunicação $e$ a atualização de como estavam companheiros $e$ a luta política era outro grande empecilho enfrentado. Segundo Liége,

Tinha uns esquemas que a gente no rádio ouvia o programa transmitido pela Rádio Tirana na Albânia sobre o Brasil. Então tinha notícias que a gente ficava sabendo, prisões que a gente ficava sabendo, notícias que a gente ficava sabendo pela Rádio Tirana, que a gente não tinha acesso aqui no Brasil. E tinha também a rádio na China que a gente da mesma forma recebia as notícias. Isso era uma coisa... A realidade era essa. Essa era a realidade de perseguição, você saia um dia, sabia que alguém tinha sido preso, tinha sido morto. E sempre esperando que o dia de amanhã fosse melhor. Então essa questão de notícias você não tinha. Tinha a notícia de que mataram, de que morreram, de que foi preso. Você via estampado em locais públicos cartazes com fotografias de pessoas que eles estavam procurando. Você reconhecia alguém, você nem podia parar. Era um momento de cerceamento das liberdades democráticas. Você tinha que se fingir de morto para poder sobreviver e continuar lutando. Parece contraditório mais era isso. Você continuava lutando, você continuava organizando divulgando. ${ }^{37}$

Durante os anos de ampla repressão do Estado, foram aprovadas diversas leis que censuravam os meios de comunicação, a exemplo da lei Falcão, criada em 1976 no intuito de regular propagandas, programas e músicas. Salientamos que outras formas de coibir qualquer meio de divulgação não ordenada já vinha sendo realizada com a criação já em 1965 do Serviço de Censura de Diversões

\footnotetext{
${ }^{33}$ Entrevista de Maria Liége...

${ }^{34}$ Entrevista de Maria Liége...

${ }^{35}$ Para além da vivência na prisão, o cotidiano da clandestinidade também marcou de forma indelével a trajetória destes exmilitantes de organizações revolucionárias brasileiras. Cair na clandestinidade era, acima de tudo, uma tentativa de sobrevivência para estes militantes políticos. Ao ingressar em uma organização da esquerda armada e/ou ao tornar se clandestino, o militante rompia de forma radical com toda sua vida anterior. Identidades falsas, "aparelhos", "pontos" e regras de segurança tornavam- se parte da rotina. O militante habitava um mundo com linguagem, leis e códigos próprios - uma existência paralela. Em muitos sentidos, cair na clandestinidade significava tornar-se um exilado dentro de seu próprio país. ARAUJO, Ditadura militar..., p. 23.

${ }^{36}$ FERREIRA, Elizabeth F. Xavier. Mulheres, militância e memória. Rio de Janeiro: Fundação Getúlio Vargas, 1996 , p. 136.

${ }^{37}$ Entrevista de Maria Liége...
} 
Públicas do Departamento Federal de Segurança Pública. Quanto aos meios de comunicação utilizados para obter notícias que ocorriam no país, além de desviar-se da censura, as rádios Tirana da Albânia e a chinesa eram vistas como importantes meio de informação para exilados e pessoas na clandestinidade. Ressaltasse que ambos os países eram de posicionamentos ideológicos de base comunista, fator esse que permitiu a entrada de muitos militantes do $\mathrm{PC}$ do $\mathrm{B}$, e do jornal $A$ classe operária em alguns de seus editoriais, fazendo transmissões em português via rádio. Assim, havia uma espécie de

(...) rede de comunicação que envolve dirigentes e militantes do PC do B, jornalistas/militantes, o jornal e rádios da China e da Albânia. Esses eram os dois países comunistas com os quais o PC do B mantinha contato. Com as dificuldades de produção e distribuição d'A Classe Operária devido à clandestinidade, textos que eram produzidos para esse jornal eram enviados para as rádios dos países amigos. ${ }^{38}$

Em 1972, Maria Liége muda-se para Recife, onde tem sua primeira filha, Helenira (homenagem à guerrilheira morta no Araguaia), e permanece até 1974. A questão da mudança de cidade era algo corriqueiro na vida das pessoas que viviam na clandestinidade, haja vista o sistema de informações do Estado, bem como as constantes perseguições e prisões. Em sua nova cidade foi trabalhar no Laboratório Central da Secretaria de Saúde do Estado. Nesse período, antes mesmo do nascimento de sua filha, viveu juntamente com seu marido, e um companheiro de partido, Raimundo Oswaldo Barroso. Neste ponto, Liége chama mais uma vez atenção para a solidariedade, algo de grande importância para a resistência. Segundo ela,

(...) a solidariedade era uma questão importante para a sobrevivência. Então, por exemplo, [...] quando eu casei, morava eu, meu companheiro e tinha um amigo que morava com a gente. Antes de eu casar eu morei com um casal. Muito antes disso em Fortaleza quando eu cheguei lá e fui morar com pessoas que me acolheram. Então isso é uma questão de solidariedade, entendeu? É um suporte. Não só vamos dizer assim... Um suporte emocional que você tem de ser acolhida entendeu? Isso também era importante. Um sentimento forte de solidariedade, de acolhimento. Isso ninguém paga entendeu? É um negócio assim muito importante, muito marcante que também tem uma relação de você preservar a vida da pessoa. De você contribuir para que pessoas voltem a ter uma vida, podemos dizer assim normal entre parênteses e entre aspas. Mas, que você tenha um... Vamos dizer assim, você sabe que têm pessoas ali que são amigas solidárias. Então a gente quando sempre fala nos simpatizantes da causa são essas pessoas que sempre manifestaram solidariedade e acolhimento, contribuíram, ajudaram para preservar vidas de pessoas. ${ }^{39}$

Nesse sentido, identificamos uma espécie de rede de solidariedade, que contribuía para a manutenção e a proteção de situações de vulnerabilidade como fome, frio, e cuidados básicos, no qual os militantes estavam expostos. Logo, assim como em tantas outras obras que se propõe a discutir a resistência à ditadura, a solidariedade $e^{40}$ é palavra chave para que muitos militantes se mantivessem vivos ou tivessem a vida preservada durante o período.

Por conseguinte, em muitos estudos que se referem a participação da mulher na resistência à ditadura, a questão da maternidade é algo quase unânime no âmbito da escolha entre militância $e$ vida pessoal. Apesar de ser vista como loucura para muitos que vivenciavam aquele período, mediante as complicações tanto para a militância, quanto para a gestação de uma criança, Liége e seu marido decidem levar a gravidez até o fim.

\footnotetext{
${ }^{38}$ MOURÃO, Mônica. Comunicação clandestina: Redes de comunicação politica durante a ditadura militar brasileira. VII Encontro Nacional de História da mídia - mídia alternativa e alternativas midiáticas. 19 a 21 de agosto de 2009, Fortaleza, p. 10.

${ }^{39}$ Entrevista de Maria Liége...

${ }^{40} \mathrm{O}$ termo solidariedade aqui utilizado se adequa ao momento histórico em questão respeitando sua polissemia. Muitos foram os regimes de exceção instaurados na história e com eles a própria particularidade conceitual da palavra solidariedade. Logo, aqui a entendemos como "identificação coletiva de doutrinas e interesses, apoiado na ideia de uma comum situação de exploração e de injustiça" RIBEIRO, Maria Cláudia B. A Resistência à ditadura civil-militar brasileira e as Redes Transnacionais de Solidariedade (1964-1985). XXVIII Simpósio Nacional de História. Florianópolis, SC, 2015 , p. 1. 
Eu me lembro que quando fiquei grávida pela primeira vez, minha companheira... eu cheguei a morar com ela e o marido. (...) Quando eu disse que estava grávida ela disse que nós éramos malucos de ter filho naquela situação. Mas, nós decidimos ter $e$ tivemos entendeu? E ela tinha filho também. ${ }^{41}$

Ao passo que a ditadura ficava ainda mais repressora $e$ a presença das mulheres dentro dos movimentos de resistência à ditadura era uma realidade, a maternidade se torna um divisor de águas em suas vidas. Algumas por motivações pessoais decidem abandonar a militância, outras sofrer com o aborto, e outras assumem a maternidade juntamente com política. ${ }^{42}$

Uma vez optando pela gestação em pleno regime, muitas viram em seus filhos uma prática desumana de tortura física e psicológica, trazendo traumas que duram até os dias atuais. Segundo Liége, "(...) algumas companheiras sofreram, aquelas presas tiveram ameaças que seus filhos seriam mortos. É uma coisa muito forte para as mulheres". ${ }^{43}$ Assim, "De certa forma, a militância em favor de uma revolução comunista significaria a negação da própria condição feminina, ou pelo menos, a negação de um determinado modelo de feminilidade". " Dessa forma, muitas mulheres rompem com o padrão cultural ocidental tão difundido, que as colocavam como incapazes de lutar por política e ter sua própria vida, com ou sem gestação, a partir de padrões estabelecidos do que era o feminino. Assim, "Eram as mulheres que precisavam conciliar a maternidade e o emprego, o cuidado dos filhos $e$ das filhas, era uma responsabilidade unicamente feminina, uma construção social e cultural e, aos homens não haveria esta cobrança". ${ }^{4}$

Em meio à repressão, muitos torturadores e agentes agiram diretamente no corpo feminino, onde "a prisão se transformou em um local de prática permanente da violência que é a tortura - a tortura como um ato de violência física que se emprega unilateralmente contra o corpo (e mente) de um adversário indefeso". "Além disso, muitas crianças foram utilizadas como artifícios para que muitos militantes fossem enfraquecidos psicologicamente, inclusive algumas sofrendo torturas. Muitas eram levadas para o cárcere em contato "com seus pais nus, machucados, recém-saídos do pau de arara ou da cadeira do dragão. Foram encapuzados, intimidados, torturados antes mesmo de nascer". ${ }^{47}$

No ano de 1974, Liége resolve ir à Bahia visitar clandestinamente sua família em Salvador, será durante o trajeto da viagem que sua casa é invadida, tendo seu marido e o companheiro do partido presos sendo levados pela polícia do estado ao Destacamento de Operações e Informações e o Centro de Operações de Defesa Interna (DOI-CODI).

Quando ela tinha dois meses [sua filha] eu resolvi clandestinamente visitar minha família aqui, fui encontrar com meu sogro em Alagoas e nesse mesmo dia a casa em Recife foi invadida. Meu ex-marido Arthur de Paula foi preso e outro companheiro Raimundo Osvaldo do Ceará que morava com a gente foi preso, barbaramente torturado os dois. (...) Vim saber de dois meses da prisão. Depois eu liguei para um local combinado, e era uns padres amigos nossos e eles não quiseram falar muito, depois fui comunicada que nossa casa tinha sido invadida pela polícia. ${ }^{48}$

Além da percepção de uma vida de grande atenção devido às ações repressivas, é possível perceber na passagem acima as relações existentes entre setores da igreja e movimentos de esquerda. Tais

\footnotetext{
${ }^{41}$ Entrevista de Maria Liége fornecida ao pesquisador em 26/02/2016.

${ }^{42}$ CONRADI, Carla Cristina N. "Memórias do sótão": vozes de mulheres na militância política contra a ditadura no Paraná (1964-1985). (Tese) Programa de pós-graduação em História. Universidade Federal do Paraná, 2015.

${ }^{43}$ Entrevista de Maria Liége...

${ }^{44}$ CORDEIRO, Janaína Martins. "A nação que salvou a si mesma": Entre memória e História, a campanha da mulher pela democracia (1962-1974). Dissertação de Mestrado, Universidade Federal Fluminense. Rio de Janeiro, 2008, p. 100.

${ }^{45}$ CONRADI, Memórias do sótão..., p. 177.

${ }^{46}$ COLLING, A resistência..., p. 79.

${ }^{47}$ SÃO PAULO, Comissão da Verdade do Estado de São Paulo "Rubens Paiva". Infância Roubada: Crianças atingidas pela ditadura militar no Brasil. Assembleia Legislativa, Comissão da Verdade do Estado de São Paulo. São Paulo: ALESP, 2014, p.11.

${ }^{48}$ Entrevista transcrita a partir do relato concedido à Comissão da Verdade Milton Santos da Universidade Federal da Bahia em 2013. Disponível em: http://www.comissaoverdade.ufba.br/node/10.
} 
contribuições foram de grande importância para a resistência e a sobrevivência de muitos presos políticos.

No tocante à invasão da residência a que Liége se refere, em relato fornecido pelo Núcleo de Cultura Política do Amazonas (NCPAM) ligado à Universidade Federal do Amazonas, Raimundo Oswaldo relata:

No final de abril de 1974, fui sequestrado pelo DOI-CODI de Pernambuco, juntamente com Arthur Geraldo Bonfim de Paula. Nós habitávamos, com a família dele, no bairro do Jordão. Nossa residência foi invadida, saqueada e ocupada por agentes de segurança. Liége, esposa de Arthur, e sua filha de um mês, Helenira, escaparam do sequestro por terem viajado na manhã anterior. ${ }^{49}$

Durante o período em que passa preso, Liége informa que Arthur de Paula, além de ser torturado, sofreu a tortura psicológica de ser informado por um agente do DOI-CODI que ela havia sido presa $e$ sua filha enviada para um asilo. Importante considerar que as informações colhidas pela ditadura eram utilizadas no contexto de relação entre torturadores e torturados. Ao saber que Arthur de Paula possuía uma família com esposa e filha, possivelmente na tentativa de desestabilizá-lo emocionalmente, a repressão proferia informações pífias e sem fundamentos. Como destaca Liége,

A casa foi invadida e ele e um companheiro que morava com a gente foram presos $e$ barbaramente torturados. Barbaramente torturados durante quarenta dias. Ficaram incomunicáveis sob tortura. E quando meu sogro conseguiu visita-lo, Miranda, que era o florido de Pernambuco, disse para meu sogro: - Fale para ele que aquilo que falei é brincadeirinha. E meu sogro não entendeu. A brincadeirinha era além barbaramente torturado, ainda fez a brincadeirinha de dizer que eu tinha sido presa e que a minha filha tinha ido para o asilo. Quer dizer que era uma tortura física, uma tortura psicológica. É uma resistência que você na clandestinidade, você está a todo momento resistindo. Você está a todo momento acreditando que é válida a luta. E é todo momento, você se manter sobre cuidados para você não ser presa e não prejudicar inclusive outros companheiros. Então é um ensinamento de vida. Ensinamento de força, um ensinamento de resistência. É um ensinamento de que lutar é preciso e de que é válido lutar. ${ }^{50}$

Em suas palavras, percebemos o quanto a resistência à ditadura e sua vivência na clandestinidade foram importantes para sua vida e composição identitária. A partir do emprego da história oral, as memórias coletadas, permitem ao pesquisador compreender que “(...) história e memória através de uma inter-relação dinâmica são suportes para as identidades individuais e coletivas que se formam no processar diacrônico e sincrônico da vida em sociedade". ${ }^{51}$ Além disso, se em muitos livros de memórias pós-ditadura, alguns militantes mostram revisões quanto a certo arrependimento de atos ou dando indícios que se pudessem voltar no tempo fariam de forma diferente, Maria Liége é bem direta, demonstrando o quanto suas posições e formas de reinterpretação de seu passado se cristalizaram. "Eu não me arrependo de nada do que fiz. Faria tudo de novo. Eu tinha consciência do que estava fazendo. Ninguém me obrigou. Eu tomei consciência de que precisava lutar para derrubar o regime militar e faria tudo de novo. O meu passado não me condena [risos]". ${ }^{2}$

Apesar do que estava ocorrendo, Liége chegou a Salvador (1974), mas por questões de segurança foi para o Rio de Janeiro e só retornou à capital baiana em julho de 1975 pondo fim a sua clandestinidade. Será nesse período que sofrerá um dos maiores traumas de sua vida, até então, a perda de sua filha Helenira devido a problemas de saúde.

Aí eu voltei em julho de setenta e cinco para Salvador. Que tinha um advogado que dizia que eu era tão louca porque tinha tido uma prisão de pessoas que era do Partido Comunista Brasileiro. Uma turma tinha sido presa. Então eu voltei em setenta e cinco.

\footnotetext{
49 Relato de Raimundo Oswaldo disponível em http://www.ncpam.com.br/2009/09/memoria-da-ditadura-passamos-47dias.html

${ }^{50}$ Entrevista de Maria Liége fornecida ao pesquisador em 09/09/2015.

${ }^{51}$ DELGADO, Lucília. Historia oral..., p. 45.

${ }^{52}$ Entrevista de Maria Liége...
} 
Eu cheguei em Julho e minha filha veio a falecer em agosto entendeu? Então foi uma situação que meu companheiro estava preso em Recife em setenta e cinco, então ele só foi liberado em dezembro de setenta e cinco. E quando foi em setenta e sete ele foi preso novamente, entendeu? Quando a minha segunda filha tinha nascido. De novo a história se repete porque na primeira vez que ele foi preso minha filha tinha dois meses. E quando a minha segunda filha tinha dois meses ele foi preso novamente. Ai ele foi para a Lemos de Brito. ${ }^{53}$

No trecho acima percebemos o quanto a ditadura não apenas cerceou o direito de vida das pessoas, bem como contribuiu para potencializar os traumas vividos. Por outro lado, Liége também vê as situações vividas naquele período como importantes para seu fortalecimento, neste caso não apenas como militante, mas como pessoa. Portanto, percebemos o quanto sua memória militante foi sendo construída ao longo do tempo, seja por motivações estudantis, pessoais e traumas vividos. Como destaca Nora, “(...) a memória não se acomoda a detalhes que a confortam; ela se alimenta de lembranças vagas, telescópicas, globais ou flutuantes, particulares ou simbólicas, sensível a todas as transferências, cenas, censura ou projeções". ${ }^{4}$

\section{Anistia, militância e perseguições}

Em 1975, na tentativa de retomar sua vida na Bahia, Liége além de voltar a trabalhar e continuou sua militância política ajudando a organizar com outras mulheres do estado o Movimento Feminino pela Anistia ${ }^{55}$, algo iniciado por Terezinha Zerbini em São Paulo. Criado em um período onde as discussões em torno da Anistia se ampliavam e pressionavam o governo militar, a grande luta do MFPA não era o julgamento de torturadores, mas a tentativa de amenizar os conflitos políticos vividos no país e tentar encontrar vestígios ou saber o paradeiro de seus entes queridos. Durante a criação do Movimento Feminino pela Anistia - BA em 1976, Maria Liége retoma o curso de Biblioteconomia na Universidade Federal da Bahia, contudo, continuava na luta politica, ainda mais que seu companheiro continuava preso.

Após ampla militância no MFPA, Liége relata que juntamente com outros militantes políticos criam o Comitê Brasileiro pela Anistia seção Bahia (CBA-BA) e posteriormente o Movimento Feminista da Bahia (MFB), onde realizavam inúmeros encontros e debates. Com base em um informe encaminhado para o Serviço Nacional de Informações (SNI), disponível no Arquivo Público do Rio de Janeiro, datado de 16 de Setembro de 1982, é possível perceber que este e tantos outros movimentos feministas estavam sendo observados pelo governo, tendo nomes de participantes e suas seções partidárias em destaque. Neste, encontramos trinta e três entidades feministas com seus respectivos nomes, espalhados em dezesseis estados brasileiros. Elencando os pressupostos para tais identificações, o documento prescreve:

1. Os vários segmentos esquerdistas, em atuação no País, consideram essencial, para combater o regime, a formação de grupos de pressão feministas.

1.1 Desse modo, os movimentos feministas vêm adquirindo grande impulso, caracterizado pelo aparecimento e ressurgimento de várias entidades que, sob o pretexto de melhorar as condições de participação da mulher na Sociedade, estão sendo manipuladas política e ideologicamente..$^{56}$

\footnotetext{
${ }^{53}$ Entrevista de Maria Liége...

${ }^{54}$ NORA, Pierre. Entre memória e história: A problemática dos lugares. Projeto História. Trad. Yara Aun Khoury. História e Cultura. Revista do Programa de Estudos pós-graduandos em História. Departamento de História, PUC-São Paulo, n.10, 1981/1993, p. 9.

55 "O Movimento Feminino pela Anistia foi criado em 1975 em São Paulo, quando oito mulheres, dentre elas Therezinha Zerbini, elaboraram, em março daquele ano, o documento 'Manifesto da Mulher Brasileira em favor da Anistia', no qual defendiam que fosse concedida a anistia para todos que haviam sido atingidos pelos atos de exceção". PAULA, Adriana das Graças de. Pensar a democracia: o Movimento Feminino pela Anistia, as Mães da Praça de Maio e os intelectuais. Anais do XI Encontro Internacional da ANPHLAC. Niterói - Rio de Janeiro, 2014, p. 1.

${ }^{56}$ ARQUIVO PÚBLICO DO RIO DE JANEIRO. Movimentos Feministas do Brasil - SNI (20/08/1982). SÆCUluM - Revista DE HistóRIa [39]; João Pessoa, jul./dez. 2018. 
É possível problematizarmos alguns pontos. O primeiro é a análise do discurso empregado pela repressão, enquadrando as movimentações feministas como "manipuladas política e ideologicamente". Com base nos dados fornecidos na documentação acima citada, os movimentos elencados só apresentam mulheres no centro das organizações, o que é possível enquadrar tal discurso repressivo como uma tentativa de menosprezar a própria capacidade organizacional e política das envolvidas. $\mathrm{Na}$ análise do discurso, o que se percebe é a repressão colocando os movimentos de esquerda enquanto detentores das ideologias da massa e sendo o detentor da ideia da criação de movimentos feministas, ao mesmo tempo em que demonstra a forma na qual as mulheres e a participação politica não apresentava qualquer autonomia politica e ideológica. Cabe mencionar que poucos foram os partidos que uma mulher chegou ao alto comando, algo que nos permite problematizar o próprio espaço dado as mulheres dentro das organizações de esquerda e o quão diferente era o tratamento.

Durante o período em que militava no MF e no CBA, Maria Liége menciona que as visitas a seu marido, também marcaram a vida de sua filha Lia. Uma vez que seu pai, Arthur de Paula, se encontrava preso em Salvador e os dias de visita era para vê-lo. Assim, devemos destacar que os traumas afetaram a todos, desde familiares à amigos próximos devido a incomunicabilidade e o cerceamento de liberdades individuais. Logo, Lia foi privada do convívio cotidiano com seu pai e seu único contato até sua liberdade era através da ida ao presidio.

Em 1979 com a aprovação da Lei de Anistia (6.683/79), o desejo de parte da ala conservadora e militar por realizar uma transição lenta e gradual de caráter apaziguador passa ser colocada em prática, onde crimes políticos de ambos os lados, segundo o texto, haviam sido anistiados. Porém, na prática, isso representou o "perdão" do estado, principalmente à torturadores e oficiais que aniquilaram pessoas e consequentemente os Direitos Humanos. Como resultado, o CBA perdeu sua força, tendo suas dissidências partindo para o recém-criado Partido dos trabalhadores (PT) e os grupos "Tortura nunca-mais" que teve inúmeras seções estaduais, a exemplo da Bahia, que permanece ativa até os dias atuais ${ }^{57}$.

Em 1982, a Associação dos Funcionários Públicos do estado da Bahia sediou o lançamento da Revista Guerrilha do Araguaia. Tal revista já havia sido lançada em algumas capitais como Rio de Janeiro e Belo Horizonte, chegando a Salvador. Contudo, será neste evento que Maria Liége conhecerá sua quarta e última prisão em 15 anos de militância.

Em decorrência de toda essa militância, em 82 eu fui presa na Associação dos Funcionários Públicos da Bahia, no lançamento do livro sobre a Guerrilha do Araguaia. Quando chegamos lá era uma plateia de umas quinhentas pessoas. Percebemos que tinha algo de estranho no ar. A polícia tinha se implantado na Associação antes que o público chegasse e nós entramos para fazer. Naquela época não tinha power point $e$ as companheiras que tinham ido a caravana, Diva Santana $e$ Elza Monerat iam fazer a apresentação dos slides da visita que tinham feito na região do Araguaia. ${ }^{58}$

Ao relembrar sua quarta prisão, Liége descreve que inicialmente são levados todos juntos para a Delegacia do Beirú (atual bairro Tancredo Neves), onde os homens ficaram divididos em duas celas e ela sozinha, ficando dez dias sem comunicação alguma. Posteriormente, segundo ela, por possuírem nível superior é que são transferidos para o Forte do Barbalho. ${ }^{59}$

Ainda em 1982, especificamente em 29 de julho, o jornal A Tarde publicou uma nota intitulada "Anistia faz queixas contra a Polícia Federal". Nesta, o CADH alega o absurdo no enquadramento de pessoas na Lei de Segurança Nacional, sendo levadas a depor na Polícia Federal. Além disso,

\footnotetext{
${ }^{57}$ LUNA, Cristina . Os sequestros de embaixadores na ditadura civil-militar. In: Gian Carlo de Melo Silva. (Org.). Os crimes e a História do Brasil: abordagens possíveis. 1 ed.Alagoas: EDUFAL, 2015.

${ }^{58}$ Entrevista transcrita a partir do relato concedido à Comissão da verdade Milton Santos da Universidade Federal da Bahia em 2013. Disponível em: http://www.comissaoverdade.ufba.br/node/10.

${ }^{59}$ Homenagem dada ao militar pernambucano Luís Barbalho Bezerra durante a luta contra as invasões holandesas de 1638 , o Forte do Barbalho foi construído em terreno doado pelos frades do Carmo, de onde veio o seu primeiro nome de Fortaleza de Nossa Senhora do Monte Carmelo (ou do Carmo). Durante a ditadura civil-militar passou a ser utilizado como prisão política, sendo em 1982 repassado para a tutela do $7^{\circ}$ Batalhão da Polícia Militar do Estado da Bahia. SANTOS, Marco Antônio dos. O papel das fortificações no espaço urbano de Salvador. Dissertação de Mestrado. PPG Geografia. Universidade Federal da Bahia, Salvador, 2012.
} 
apresenta o advogado Augusto de Paula como um dos membros da equipe de defesa aos presos políticos, finalizando com uma acusação à $\mathrm{PF}$ de cometer crimes como a invasão que caracterizou o incidente. Durante sua quarta passagem em cárcere, Maria Liége relembra a visita que teve de sua filha e seu marido. Segundo ela, em decorrência de sua demora em retornar para casa e a constante falta sentida principalmente por sua filha, Arthur de Paula resolve ir visitá-la.

Depois de alguns dias meu ex-companheiro resolveu levar as meninas para me visitarem porque ele disse que primeiro que estava viajando. Tava demorando muito teve que me levar para me ver. E depois disso, por muito tempo quando ela andava com a gente pela rua segurava na mão e perguntava: - "Esse é do bem ou do mal?" porque o do mal era porque tinha levado a mãe delas presa. ${ }^{60}$

Neste caso, percebemos que os traumas do período transcenderam a vida política de seus pais, invadindo o senso cognitivo e o entendimento da filha do casal que, ao andar pela rua, ao ver um soldado, questionava ser do bem ou do mal. Em 2014, a Comissão da Verdade do Estado de São Paulo lançou a obra Infância Roubada - Crianças atingidas pela ditadura militar no Brasil, o qual busca apresentar diversas crianças que assim como Lia, tiveram a vida impactada por seus pais serem presos políticos.

No ano de 1984, Maria Liége ainda sofreu uma nova invasão à sua residência. Chama atenção o ano citado por ser um período em que as discussões de abertura política já tinham recebido grande destaque, algo que confirma nossa constatação de que no período chamado "abertura política", a repressão continuava ativa, ainda que em escala menor.

Em 84 a minha casa, meu apartamento no Cata-Vento em Brotas foi de novo invadido pela Polícia Federal. Que levaram mais de cinquenta livros nossos, ficaram a manhã inteira revistando almofada, brinquedos etc. O vizinho, amigo nosso, viu aquela confusão, o cara de metralhadora em meu apartamento, meu apartamento era térreo. Ele avisou a uma amiga para que fosse pegar minha filha na escola para que ela não visse àquela ocasião. Elas conseguiram pegar uma e outra não. Lia a mais velha quando chegou no apartamento e viu aquela bagunça disse: "Eles vieram buscar meu pai". Porque a menina estava apavorada. ${ }^{61}$

Apesar das constantes perseguições e ataques autoritários que ainda se faziam presente, Maria Liége continuou militando nos movimentos políticos sociais já com seu marido em liberdade. Em 1985, após todos os anos de perseguição política, Maria Liége passou a atuar na comissão que levou à criação do Conselho Municipal dos Direitos da Mulher, na Assembleia Legislativa, sendo eleita ainda neste ano presidenta da União de mulheres de Salvador.

Já em 1986, mudou-se para São Paulo, onde passou a trabalhar no Conselho Estadual da Condição Feminina e na Secretaria Especial de Politicas para as Mulheres onde continuou sua militância pela democracia e pelos direitos das mulheres.

As mulheres sempre estiveram presentes na luta pelo voto, na luta contra a ditadura na luta pela anistia. Quem começou o movimento pela anistia foram as mulheres, como o movimento feminino pela anistia. As mulheres tiveram um papel importantíssimo na constituição de oitenta e oito na constituição brasileira, entendeu? Apresentaram... tanto que na época a constituição foi considerada uma das mais avançadas do mundo dos direitos das mulheres porque nós estávamos lá, presente como dom, como manifesto a constituintes e continuamos hoje na luta entendeu. Continuamos hoje na luta pelas garantias das políticas públicas das mulheres. Conquistamos a lei "Maria da Penha", conquistamos um plano nacional de política para as mulheres. Conquistamos a secretaria de políticas para as mulheres, então essa participação das mulheres ela é evidente, eu costumo dizer quando eu vou fazer

\footnotetext{
${ }^{60}$ Entrevista transcrita a partir do relato concedido à Comissão da verdade Milton Santos da Universidade Federal da Bahia em 2013. Disponível em: http://www.comissaoverdade.ufba.br/node/10.

${ }^{61}$ Entrevista transcrita a partir do relato concedido à Comissão da verdade Milton Santos da Universidade Federal da Bahia em 2013. Disponível em: http://www.comissaoverdade.ufba.br/node/10.
} 
palestra. Eu costumo dizer o seguinte: "Nós não somos mais cidadã de... Nunca fomos mas, eram consideradas cidadãs de segunda categoria. Nós não somos cidadã de segunda categoria, nós não somos sexo frágil, nós não somos atrizes coadjuvantes. Somos protagonistas da história. ${ }^{62}$

Como destaca Liége, as mulheres estiveram presentes na luta politica, seja pela anistia ou no processo constitucional escrito em 1988. De fato, as mulheres sempre estiveram como atuantes nas diversas lutas que o Brasil enfrentou, ainda que mergulhadas em uma cultura patriarcal e que muitas vezes determinava o que era coisa de mulher e coisa de homem. Além disso, destaca a luta atual no qual esta envolvida, não deixando ser uma porta voz de movimentos feministas, rompendo com a concepção patriarcal de sexo frágil e longe do cenário público.

\section{Conclusão}

Em meio ao processo de abertura política e os dias atuais, lá se vão mais de três décadas e com elas histórias mal contadas e perguntas eternamente sem respostas. Até hoje, muitos corpos de militantes políticos não foram encontrados; o que se tem são memórias de parentes, amigos, familiares $e$ companheiros. Memórias essas que vêm ao longo dos últimos anos recebendo atenção cada vez maior por parte de pesquisas e (re) construção de trajetórias políticas.

O presente artigo buscou, ainda que de forma sintética, a partir das reflexões apresentadas pela exmilitante politica Maria Liége, problematizar os inúmeros episódios que ocorreram durante a ditadura civil-militar brasileira e os impactos gerados em sua vida e de pessoas a ela ligadas.

Entendemos que qualquer pessoa é fruto do seu tempo e o quanto as subjetividades impactam diretamente nos processos de rememoração, ao serem expostos. Ou seja, nossas lembranças foram inspiradas ao longo de nossas vivências e diálogos, que são enriquecidos pelas experiências $e$ embates. ${ }^{63}$ Logo, se hoje, em nossas conversas, Maria Liége vê a presença das mulheres como cidadãs (e não sexo frágil), mas acima de tudo como protagonistas da História, isso só foi permitido através da construção identitária que se deu ao longo de suas relações sociais de vida e experiências vividas. Quanto à sua militância, com o passar dos anos os diálogos se cristalizaram, tendo poucas alterações com o tempo, agrupando novas ideias e ressignificações, mas sem alterar o que se formou em sua memória de militante política.

Ainda que este texto possa parecer uma construção/exaltação à personagem aqui apresentada, reiteramos que o principal objetivo deste breve artigo foi problematizar a presença da mulher e do Nordeste no processo de construção de militância e resistência política durante a ditadura. Maria Liége, assim como tantas outras/outros militantes, escreve suas memórias e as transcreve a partir de suas subjetividades, algo visto por nós com o cuidado inerente ao oficio de historiador (a).

Justificativas, dados imprecisos, momentos de euforia, de lágrimas e de sorrisos é o que marca a relação entre a memória e a desvencilhável subjetividade. Não cabe analisar buscando uma verdade, mas ter consciência das verdades que a todo momento nos cercam, seja em nossas pesquisas ou em nossas escolhas. Contudo, nunca devemos esquecer o período de grande "atraso" político e de total desrespeito aos direitos políticos, sociais e humanos que o Brasil viveu a partir de 1964, algo que nos últimos anos ganhou contornos de revisionismo por alas conservadoras, que desconsideram os atos $e$ se apegam às causas que levaram às práticas desumanas e ao número de torturados/mortos. Contudo, é importante estarmos sempre lembrando o que ocorreu durante o período ditatorial iniciado em 1964 para que nunca mais tenhamos que conviver com uma ditadura, seja qual for sua natureza.

\section{ecect}

\footnotetext{
${ }^{62}$ Entrevista de Maria Liége...

${ }^{63}$ BOSI, Ecléa. Memória e sociedade: lembranças de velhos. 4. ed. São Paulo: Companhia das Letras, 1995. 


\section{RESUMO}

$\mathrm{O}$ presente artigo, oriundo de minha pesquisa de mestrado, busca a partir das memórias de uma ex-militante política, analisar como se deu o processo de sua trajetória e a relação direta com a Ditadura Civil-Militar instaurada em 1964. Fazendo uso da história oral como método, neste trabalho serão analisados os episódios narrados levando a contento as subjetividades e a relação com o tempo presente no seu processo de rememoração/construção. Perpassando a formação política, o movimento estudantil bem como prisões e perseguições vivenciadas, a partir da experiência de Maria Liége, esperamos contribuir em reflexões que tangenciem o período e a relação direta entre a participação da mulher na resistência política. Para isso, levaremos em consideração a visão da esquerda e dos órgãos de repressão acerca das militantes, tendo a memória de nossa personagem relações diretas com o que é dito e com que foi vivido. Por fim, o presente trabalho busca problematizar a região Nordeste do país não como zona de recuo de militantes perseguidos em outras regiões, mas, também, detentor de uma forte estrutura de repressão e de perseguição. Logo, concluímos que as mulheres tiveram importância para o processo de resistência contra a ditadura, bem como houveram inúmeros focos de luta política fora do eixo Sul-Sudeste.

Palavras-chave: Ditadura; Mulheres; Memória.
This article, from my master's research, searches from the memoirs of a former political activist, to analyze how the process of her trajectory occurred and the direct relationship with the Civil-Military Dictatorship established in 1964. Making use of history oral as a method, in this work will be analyzed the narrated episodes leading to content subjectivities and the relationship with the present time in its process of recall/construction. Through political experience, the student movement as well as prisons and persecutions experienced, from the experience of Maria Liége, we hope to contribute in reflections that cross the period and the direct relation between the participation of the woman in the political resistance. To do this, we will take into account the vision of the left and the repressive organs around the militants, with the memory of our character direct relations with what is said and lived. Finally, the present work seeks to problematize the Northeast region of the country not as a zone of retreat of militants persecuted in other regions, but also, has a strong structure of repression and persecution. Therefore, we conclude that women played an important role in the process of resistance against the dictatorship, and there were innumerable foci of political struggle outside the South-Southeast axis.

Key words: Dictatorship; Women; Memory.

Artigo recebido em 24 jul. 2018.

Aprovado em 26 ago. 2018. 
